\title{
Cyber Bullying in Youth Generation and Social Media Regulation
}

\author{
Ressi Dwiana1, Rehia K. Isabella Barus² \\ Communication Science Study Program Social and Political Science Faculty ${ }^{12}$ \\ Universitas Medan Area, Medan, Sumatera Utara, Indonesia \\ ressidwiana@yahoo.com ${ }^{1}$
}

\begin{abstract}
This article explore teenager perception about cyberbullying and their reaction about it. Using quantitative method, researcher measured them with single table analysis. The research finds that most teenager have strong disagreement about cyberbullying. Even though they against bullying behavior, most teenager will not do anything to prevent or stop cyberbullying. Therefore author explore more deeply this result qualitatively by analyze social media regulation especially on institutional and ethic matter. Further research should explore deeply about teenager environment, such as school or family to find more effective tools to prevent cyberbullying and its effects.
\end{abstract}

Keyword: cyberbullying, teenager, social media

\section{INTRODUCTION}

Rapid technological developments have changed our communication and interaction. In our social environment, like never before, internet enable us to connect or disconnect with almost everyone who are in the internet. When we have a clue, e. g. name, school, office, or other information, we could do many things. We can google them, find them in social medias, even search for the phone number or the address. And all those things are effortless activity, just one click away.

This virtual world gives us a new landscape where we can do nearly all real activities. Sometimes, it makes us difficult to distinguish whether is it real event or virtual one. Internet, especially social media has broaden their features, from posting words, picture, videos, sharing and commenting them. Our focus on the usage of social media by teenager base on the risk of mental and emotional safety of young generation. Teenagers are in a period of rapid development, growth, and maturation (Ahn, 2011: 1435). Their connection to social media frightening us because various platforms of social media brings more risk and negative impact for teenager.

One of negative use of social media is cyberbullying. Taken from the platform of new media, cyberbullying is expansion of bullying behavior in real life. Teenager is a phase of transition between childhood into adulthood. In this age, this group is in the process of finding their identity. As a teenager, cyberbullying behavior can affect them, whether as victim or bullier.

Concern about cyberbullying can not be separated by drastic increase of internet consumption by young people. For example, an Eurobarometer survey conducted in 29 European countries in 2008 on 12,800 parents who has children between $6-17$ years were selected randomly, describe the Internet activity of their children. The report shows a growing number of children using the internet and they use it more often than older people. In general, three quarters of parents expressed that that their children use the internet regularly (http://ec.europa.eu/public_opinion/flash/fl_248 _en.pdf, accessed on August 22, 2016).

The phenomenon also occurred in Indonesia. Internet consumption by children with mobile devices and smart phones increasingly play an important role (52\%). Most children $(80 \%)$ use the internet to search for data and information, especially for school assignments, or to meet friends online (70\%) through social media platforms. Another large group access music (65\%) or video sites (39\%) (http://www.unicef.org/indonesia/id/media_221 69.html, accessed on August 22, 2016).

The increasing use of the internet is supported by cheaper price of a gadget that allows everyone to access internet. Data in 
August 2015 indicated that the development of mobile social media users grew by $23.3 \%$ (http://wearesocial.com/sg/special-

reports/global-statshot-august-2015, accessed on August 10, 2016).

Alongside with the growth of young people internet users, negative impacts shows by data from Indonesia National Police (Polri), where in 2012, there were only 816 cases of cybercrime. The number increased to 1,237 cases in 2013 (http://www.merdeka.com/peristiwa/polribelum-tuntaskan-833-kasus-cyber-crime-di2013.html, accessed on August 22, 2016). One form of crime in the virtual world is cyberbullying.

Bullying via internet come with many formats. From soft mocking to physical threat. Teenager involvement differs also, they can be victim or the intimidator. The scope start from small community to national level. One case took public attention recently is Sonya Depari case. As a teenager, she was acting ridiculously when she and her teenage friends stopped by police officer on the road. Taking her uncle position in National Anti-Drugs Body, she tried to mock the officer. In the same place some reporters recorded her and put it on website. Spread out, shared, and bullied by a whole nation on internet, Sonya's father died of heart attack.

\section{THEORETICAL CONCEPT}

\section{A. Cyberbullying}

According to the Merriam-Webster dictionary, cyberbullying means a form of "threat" or "attack" committed by a person against another person delivered via electronic messages through the media. Manesini et al (2011: 1) defines cyberbullying as an aggressive behaviour, frequent, repeated, and aimed at causing harm to someone who is unable to defend him/herself carried out with with electronic forms of contact include harassing and threatening by phone calls, text messages, e-mails, defaming websites, and compromising photos or videos circulating on mobile phones.

Based on the researches that has been conducted since 2002, with more than 12,000 cases in 80 schools with quantitative and qualitative methods, Patchin and Hinduja (2012: 15-17) summarize 9 types of cyberbullying:

1. Been cyberbullied

2. Someone posted mean or hurtful comments about me online.

3. Someone posted mean or hurtful picture of me online.

4. Someone posted mean or hurtful video of me online.

5. Someone created a mean or hurtful webpage about me.

6. Someone spread rumors about me online.

7. Someone threatened to hurt me through a cell phone text message.

8. Someone to hurt me online.

9. Someone pretended to be me online and acting in a way that was mean or hurtful.

While Marcum and Higgins (in Jennings, 2016: 2) mentions various forms of behavior which may constitute cyberbullying:

A Harassment in the cyber form entails repetitive messages, generally offensive to the recipient. The offender may send e-mails or instant messages insulting or taunting the victim.

A Outing and trickery refers to the unintended sharing of personal information with others. A victim may have her social security number, telephone numbers, or sexual preference exposed without permission.

A Flaming occurs in a public setting, such as a chat room or discussion board, and is a brief exchange of insults between two or more parties. This could be considered a virtual argument.

A Denigration involves posting information about another that is disparaging and untrue. For example, an offender may post on a victim's Facebook page that she is a drug addict, a slut, or a person without friends.

A Exclusion/ostracism is the perception or feeling of being left out. This isolates the victim.

The effect of cyberbullying associated with lower self-esteem, heightened anxiety, heightened depression, a higher number of school absences, aggressive behavior, substance abuse, and greater physical symptomology and not knowing the identity of the perpetrator may heighten feelings of powerlessness in the target (Agatson, Kowalski, and Limber, in Patchin and Hinduja, 2011: 64).

Cyberbullying only one of negative effect of new media, especially social media. As predicted predicted long time ago by the experts that the internet has become the driving factor in the changing global communications also increased conflict in various aspects (Bagdikian, 2004: 5859). 
According to a global survey conducted by Latitude News, Indonesia is a country with cases of bullying second highest in the world after Japan. Bullying cases in Indonesia turned out to defeat the case of bullying in the United States, who in third position. Ironically, cases of bullying in Indonesia is mostly done on social networks (http://www.latitudenews.com/story/whatcountry-has-the-most-bullies-2/, accessed on April 22, 2015).

In Indonesia context, research about cyberbullying has risen and differ in many aspects. We noted some of them below:

1. Rahayu (2012) tried to investigate cyberbullying as negative impact of information technology.

2. Satalina (2014) who explore cyberbullying behavior in relation with extrovert and introvert personality.

3. Nasurullah (2015) examine cyberbullying on PR's facebook account of Indonesian Police Department.

\section{B. Social Media Regulations}

New technologies create new sites of concern. The rise of the internet and social media have reinforced and magnified existing fears while also creating a new target to blame: technology (Boyd and Hargittai, 2013: 248).

To anticipate the widespread of cyberbullying effect, regulation matter e. g. law enforcement is seen to be one the best solution. Therefore, researches about exploration of cyberbullying in correlation with law and regulation is not something really new observation. Altobelly (2010: 459) explain that cyberspace as a new frontier for both international and domestic family law where on the one hand it presents great opportunities for society, and on the other, great dangers, particularly for children. Therefore he explored a number of issues from a domestic and international family law perspective.

The reason why it is important to examine cyberbullying phenomenon with formal regulation because it is expected that the certainty and severity of formal sanctions prevent criminal acts (Xu et al, 2015). The new landscape of media comes with specific style of regulation. $\mathrm{Xu}$ et al (2015) noted that the online community's policy against internet aggression is related to a formal sanction, because users violating the policy may be punished by being discredited and de-ranked or user account deactivation.

In international level, there some formal regulation regarding to child protection from internet negative impacts. As Altobelli (2010: 471) noted, there are UN Convention on the Rights of the Child (called CROC), which was adopted by General Assembly resolution on November 20, 1989, and came into force on September 2, 1990. For example, Article 16 dealing with privacy can be applied to cyberabuse by publication; Article 17 (e) to exposure to inappropriate material; Articles 32 (l) and 34 to sexual exploitation and child pornography.

Boyd and Hargittai (2013: 249) examine regulation against negative impacts of internet in US. They mentioned that fears of online safetyrelated issues have prompted a wave of media stories and regulatory efforts. In 1998, the U.S. Congress passed two pieces of legislation meant to address problems that were perceived to be caused by the Internet: (1) the "Children's Online Protection Act (COPA)" - a law intended to limit minors' access to harmful content, an act that was deemed unconstitutional; and (2) the "Children's Online Privacy Protection Act (COPPA)" - a law intended to empower parents and protect children's privacy, which is still in place today. Since then, numerous legislative efforts have been made to address a wide array of online safety concerns, including bills meant to address sexual predators, cyberbullying, and sexting.

Beside formal (state) regulation, prevention of cyberbullying also related with domestic rules, especially in school. Porter et al (2016: 34) for example explored the practice of making local regulation in school. He said that school put 'guidelines' together for schools and the school governing bodies themselves then set specific rules and regulations.

It is not easy to establish specific rules in school. Willard (in Patchin and Hinduja, 2011: 3656) examine some cases in US where students and their parents sued school administrator because of restriction of student personal digital devices in school. Whether there is resistance about limitation on digital tool usage, some school still concern to continue their efforts in battle cyberbullying in school territory. Sabella (in Patchin and Hinduja, 2012: 72-92) investigate the important role of school counselor to prevent cyberbullying. 


\section{Cyberbullying and Social Media Regulation Fears}

Base on theoretical concepts above, we found that there still gap in cyberbullying research and regulation matter. What define cyberbullying in this context, is not the behavior of intimidation per se, instead teenager perspective of this matter and how their reaction about it.

The gap that we want to fill base on previous research, we found that whether there is strong disagreement about cyberbullying, but their reaction is contradictory (see result and discussion). Therefore, we believe that there is some variable that should be examine more deeply, using qualitative perspective to explain this phenomenon. In this research the variable that we will explore is relating to social media regulations. Regulation that we will specifically examine will lay in macro level where we explore state regulations and organizations relating to cyberbullying.

\section{RESEARCH METHODS}

Researchers use two methods, both quantitative and qualitative, to explain cyberbullying phenomenon. First method is quantitative, using survey to measured teenager opinion and reaction about cyberbullying. As Babbie (2008: 270) explain that survey is probably the best method available to the social researcher who is interested in collecting original data for describing a population too large to observe directly.

On this survey, researcher using questionnaire with two model of question forms, they are open-ended question and close-ended question. As Neuman (2011: 324) explain that close-ended is very useful in large-scale survey because they are faster and easier for both respondents and researchers, yet we can lose something important. And to learn how a respondent thinks and discover what is important to him or her or for questions with numerous answer categories, open questions are best.

This study was conducted in three favorite high schools in Medan city of tenth grade students, SMA Negeri 1 Medan, SMA Negeri 3 Medan and SMA Negeri 4 Medan. Total population of these three high schools is 4,445 students.

Sampling technique using Slovin formula:
$n=\frac{\mathrm{N}}{\mathrm{Ne}^{2}+1}$

$\mathrm{n}=$ number of samples

$\mathrm{N}=$ number of population

$\mathrm{e}=$ sampling error.

Number of population ( $\mathrm{N}$ ) is 4,445 students, assuming the standard error (e) is $10 \%$, then the sample size (n):

$n=\frac{4,445}{4,445(0,1)^{2}+1}=100$

In this study, total sample (n) is 100 respondents. Then, to determine who the sample, using accidental sampling method, the students who attended the class when in the time of research.

For further comprehension of cyberbullying phenomenon, researchers using qualitative analysis. As noted on theoretical concept, relationship among cyberbullying and regulation policy has tested by some researchers. Babbie (2008: 416) explain that in linking theory and analysis, the more our research confirms a particular set of relationship among particular concept the more confident we become that our understanding corresponds to social reality. As in this research, aimed to find cause of teenager reaction on cyberbullying. To examine this quantitative data, researchers look for patterns appearing in social reality. Huberman and Miles (in Babbie, 2008: 416) suggest variable-oriented analysis, an analysis that describe and/or explain particular variable. In this case, social media regulation is one of variable that possible to explore regarding to teenager reaction of cyberbullying.

\section{RESULT AND DISCUSSION}

Exploration of perception about cyberbullying on this research lays in two assumptions that if teenager disagree about bullying, they should have taken active reaction to halt or prevent it. Using single table analysis, we found different situation.

\section{A. Perception about Cyberbullying}

Perception about cyberbullying measured by some questions. The most expressive acknowledgement is teenager assumption about bullier. As shown below, most of respondents very agree that bullier is a mean person. 
Table 1. I assume that bullier is a mean person

\begin{tabular}{|c|c|c|c|c|c|c|}
\hline & $\begin{array}{c}\text { Very } \\
\text { Disagree }\end{array}$ & Disagree & $\begin{array}{c}\text { Not } \\
\text { Sure }\end{array}$ & Agree & $\begin{array}{c}\text { Very } \\
\text { Agree }\end{array}$ & Total \\
\hline $\mathbf{n}$ & 6 & 2 & 15 & 32 & 45 & 100 \\
\hline$\%$ & 6 & 2 & 15 & 32 & 45 & 100 \\
\hline
\end{tabular}

\section{B. Reaction about Cyberbullying}

Another measurement that researcher put in the questionnaire is about teenager reaction about cyberbullying. Using open-ended question, researcher try to give wider space on describing their reaction. What surprising us is base on the answers, most respondents choose to do nothing and avoid to get involved in cyberbullying case that they see. The other reaction, consist of some action such as report or blocking the bullier account, report to teacher, and directly criticize the bullier. We categorize those reaction as activity to stop bullying. But, as shown below, the number of apathetic reaction is the biggest one.

Table 2. Reaction about cyberbullying

\begin{tabular}{|c|c|c|c|}
\hline & $\begin{array}{c}\text { Do not do } \\
\text { anything / avoid } \\
\text { to get involve }\end{array}$ & Try to stop & Total \\
\hline $\mathbf{n}$ & 84 & 36 & 100 \\
\hline$\%$ & 84 & 36 & 100 \\
\hline
\end{tabular}

\section{Social Media Regulations}

We examine social media regulations in macro level of practice. We point out macro level as state enforcement to protect children from negative effect of new media, such as cyberbullying. Here we explore some regulation and organization which connected with cyberbullying prevention and case handling.

\section{Law}

At least there are 3 acts that protect children from misuse of new technology. They are: Indonesian Criminal Act (KUHP), Information and Electronic Transaction Act 11/2008 (UU ITE), and Children Protection Act 35/2014. Here is the detail of each regulation related to cyberbullying.

A Indonesian Criminal Act (KUHP). Article 310 Paragraph 1 which reads

(1) Whoever intentionally attack the honour of good name of someone with an impute, which mean so that it is known to the public, was threatened with imprisonment because of contamination longest nine months or criminal fines at most four thousand five hundred rupiahs.

(2) If it is done by writing or the image that is published, demonstrate or affixed to the genaral advance, then threatened due to defamation writing with an imprisonment of no longer than one year four months or criminal fines of four thousand five hundred rupiahs.

A Information and Electronic Transaction Act 11/2008 (ITE). There is one article on this act that regulate cyberbullying behavior, it is Article 27.

(1) Each person intentionally and without right distribute and/or transmitting and/or make the accessible of electronic information and/or electronic documents which have a charge of violation of decency.

(2) Every person intentionally and without right distribute and/or transmitting and/or make the accessible of electronic information and/or electronic documents which have a gambling charge.

(3) Any person knowingly and without the right distribute and/or transmitting and/or make the accessible of electronic information and/or electronic documents which have a charge of insult and/or defamation.

(4) Any person knowingly and without the right distribute and/or transmitting and/or make the accessible of electronic information and/or electronic documents which have a charge of extortion and/or threatening.

A Children Protection Act 35/2014 is revision of Children Protection Act 23/2002. In this revision, there is some restriction with punishment on child abuse. Article 76 Paragraph C, which read "Everyone is prohibited to place, let, do, told to do, or participate in violence against children".

As seen above there is no explicit word of "cyberbullying" in those regulations. Even though "cyberbullying" has translated in Bahasa Indonesia as "perundungan siber" that terminology has not described clearly in those regulations. If there is case about cyberbullying, then law officers will refer in to those article.

\section{State Organizations.}

A Communication and Information Ministry 
(Kemenkominfo).

In recent years, this government body eagerly to filter internet content. But what most dominated work of the minister is pornography related content.

A Indonesian Telecommunication Regulatory Authority (BRTI)

A lot of expectation we wish to happened when read this organization. But in practice level, this organization more focus on prohibition of monopolistic practice and unfair business competition (http://www.brti.or.id/tentang-brti, accessed on November 10, 2016)

Internet misuse often seen in many perspective, cyberbullying especially against children, only small part of the effect. Still, on this era, cyberbullying must be anticipated more effectively. Regarding to our research, teenager awareness of cyberbullying does not automatically bring proper action to prevent cyberbullying. From the regulation perspective, we can see that there is no clear definition about it or specific state organization who handle this matter. It supposable have connection because there is no clear impact or risk when teenager are facing cyberbullying, whether as victim or bullier.

\section{CONCLUSION}

From this study it can be concluded that cyberbullying prevention efforts should do more. Teens who are already aware of the act of cyberbullying should be able to be driven to take preventive action. In this research we found that there is lack on regulation matter on cyberbullying prevention. It means that state needs to make more clear definition and assign specific body to handle cyberbullying case especially which against teenager.

\section{REFERENCES}

Agatson, P et al. (2012). "Youth Views on Cyberbullying" in Patchin, J. W, and Hinduja, S. (Eds), Cyberbullying Prevention and Response: Expert Perspectives, Routledge, New York, NY, pp. 57-71.

Ahn, J. (2011). "The Effect of Social Network Sites on Adolescents' Social and Academic Development: Current Theories and Controversies", Journal of The American
Society for Information Science and Technology, Vol. 62 No. 8, pp. 1435-1445.

Altobelli, T. (2010). "Cyber-abuse - A New Worldwide Threat to Children's Rights", Family Court Review, Vol. 48 No. 3, pp. 459481.

Babbie, E. (2008). The Basic of Social Research, Thomson Wadsworth, Belmont.

Bagdikian, B. H. (2004). The New Media Monopoly, Beacon Press, Boston.

Boyd, D, and Hargittai, E. (2013). "Connected and Concerned: Variation in Parents' Online Safety Concern", Policy and Internet, Vol. 5 No. 3, pp. 245-269.

Jennings, W. G. (2016). The Encyclopedia of Crime and Punishment, John Wiley \& Sons, Inc, New Jersey.

Manesini, E, et al. (2013). "Morality, Values, Traditional Bullying, and Cyberbullying in Adolescence", British Journal of Developmental Psychology, Vol. 31, pp. 1-14.

Nasrullah, R. (2015). "Perundungan Siber (Cyberbullying) di Status Facebook Divisi Humas Mabes Polri", Jurnal Sosioteknologi, Vol. 14 No. 1, pp. 1-11.

Neuman, W. L. (2011). Social Research Methods: Qualitative and Quantitative Approaches, 7th edition, Pearson, Boston, MA.

Patchin, J. W, and Hinduja, S, (2012). Cyberbullying Prevention and Response: Expert Perspectives, Routledge, New York, NY.

Porter, G, et al. (2016). "Mobile Phones and Development in Sub-Saharan Africa: From Youth Practice to Public Policy", Journal of International Development, Vol. 28, pp. 2239.

Rahayu, F. S. (2012). "Cyberbullying sebagai Dampak Negatif Penggunaan Teknologi Informasi", Journal of Information System, Vol. 8 No. 1, pp. 22-31.

Sabella, R. (2012). "Cyberbullying, How School Counselors Can Help", in Patchin, J. W, and Hinduja, S. (Eds), Cyberbullying Prevention and Response: Expert Perspectives, Routledge, New York, NY, pp. 72-92.

Satalina, D. (2014). "Kecenderungan Perilaku Cyberbullying Ditinjau dari Tipe Kepribadian Ekstrovert dan Introvert", Jurnal Ilmiah Psikologi Terapan, Vol. 2 No. 2, pp. 294-310.

Willard, N. (2012). "Cyberbullying and The Law", in Patchin, J. W, and Hinduja, S. (Eds), Cyberbullying Prevention and Response: 
Expert Perspectives, Routledge, New York, NY, pp. 36-56.

$\mathrm{Xu}, \mathrm{B}$, et al. (2015). "Internet Aggression in Online Communities: A Contemporary Deterrence Perspective", Information System Journal, Vol 26 Issue 6, pp. 641-667. 